\title{
AN INTRODUCTION TO SELECTED INNATE IMMUNE- RELEVANT GENES IN FISH
}

\author{
ABO-AL-ELA, HAITHAM G. \\ Animal Health Research Institute, Shibin Al-Kom Branch, Agriculture Research Centre \\ El-Minufiya, Egypt \\ e-mail:haithamgamal2@gmail.com; aboalela@ahri.gov.eg; phone: +20-12-2469-5931
}

(Received $6^{\text {th }}$ Aug 2017; accepted $5^{\text {th }}$ Dec 2017)

\begin{abstract}
Aquaculture (aquafarming) especially that related to fish receives a great deal of attention because of its importance to science and economy. To illustrate, aquaculture is a fast growing sector of industry, and a source of many materials, as well as fish act as a good model for scientific research. The immune system has two main arms: innate (non-specific) and adaptive (specific). Innate immunity acts as a firewall not only against pathogens, but also against any foreign bodies, chemical agents or even environmental changes. However, there are many members of such system; but everyone has a particular function, like players in an orchestra. Fish rely mainly on their innate immunity; many studies were done to characterise, determine or understand the behaviour of immune-related genes in normal and disease conditions. To harness the real power beyond natural or innate immunity, we should understand the function of their members or genes. Herein, this review summarises and focuses on some genes related to innate immunity in different fish species.
\end{abstract}

Keywords: aquaculture, fish immunity, gene expression, immune-related genes, innate immunity

Abbreviations: CAS - cellular apoptosis susceptibility; dph - days post-hatching; GST - glutathione $S$ transferase; IFN - interferon; Ig - immunoglobulin; IL - interleukin; IL1ra -IL1 receptor antagonist; MT - 17 $\alpha$-methyltestosterone; $\mathrm{Mx}$ - myxovirus resistance; NCCs - non-specific cytotoxic cells; NK - nature killer; PAMP - pathogen associated molecular pattern; PRRs - pattern recognition receptors; Th1 - Thelper1; TLR - toll-like receptor; TNF - tumour necrosis factor; VTG - vitellogenin

\section{Introduction}

The immune response is a cascade of diverse reactions and proceedings that aims to eliminate the recognised foreign agent. Although specific or non-specific immunity are both important ways of the immune response, the non-specific immune response is the first step and the ready weapon for fighting pathogens. The immune system is very sensitive and they can be affected by exogenous treatment or change. Thus, for instance, it can be inferred that a set of genes related to immunity were greatly disrupted during and after stopping the 17 $\alpha$-methyltestosterone (MT; commonly used hormone in monosex production) treatment in the Nile tilapia, Oreochromis niloticus (Abo-Al-Ela et al., 2017a; Abo-Al-Ela, 2018).

Identification of genes that related to immunity in fish and determination of their expression patterns receive a great attention. Mostly, the increase in the expression of immune genes is usually considered as a sign for immune stimulation or enhanced immune response; however, recently, Nile tilapia received MT for a short period showed an up-regulation in the expression of innate immune genes, but with a marked decrease in the phagocytic activity and index, and genotoxicity. On the other hand, those exposed to vitamin C alone or plus MT showed somewhat normal expression of the same genes with a significant enhancement in several immune parameters (Abo-Al-Ela et al., 2017b). 
There are many genes involved in the immune response either via direct or indirect way. This review looks at some of the key elements or genes of innate immunity. It focuses on the potential function of these genes and the change in its gene expression in normal and abnormal cases.

\section{Selected innate immunity-relevant genes}

\section{Toll-like receptors $($ tlr $)$}

The main difference between innate and adaptive immunity is the type of receptors used to recognise pathogens (Medzhitov, 2007). Innate immune recognition depends on number of receptors, including pattern recognition receptors (PRRs) with a broad specificity that have evolved to sense the pathogen associated molecular pattern (PAMPs) (Janeway and Medzhitov, 2002; Medzhitov and Janeway, 2002). There are many functionally distinct classes of PRRs; however, the best characterised are tolllike receptors (TLRs) (reviewed in Alvarez-Pellitero, 2008).

PRRs are classified into two groups: cytosolic and membrane bound receptors. The membrane bound receptors, including the TLRs, detect viral nucleic PAMPs inside the endosomal compartment where numerous viruses lose their coat and expose their genome for replication and transcription. TLR7 and TLR8 sense the single stranded RNA PAMPs and cytosine-phosphate-guanosine motifs of DNA (Kawai et al., 2004; Liu et al., 2011b; Zou and Secombes, 2011; Zhang and Gui, 2012). TLRs found on phagocytic and epithelial cells recognise different pathogen (Akira et al., 2001; Takeda and Akira, 2001; Alvarez-Pellitero, 2008). For example, Tlr7 can recognise viruses (Lee et al., 2013) and initiate an IFN (interferon) response against viruses (Baum and Garcia-Sastre, 2010), bacteria (Kumar et al., 2011) and parasites (Zhao et al., 2013).

The constitutive gene expression of $t \operatorname{lr} 7$ was found in several organs and tissues in zebrafish at different stages of development (Jault et al., 2004), and in other fish species (Tanekhy et al., 2010). Salmon $t \operatorname{tr} 7$ gene expression was sensitive to Ifn and Il (interleukin) $1 \beta$ (Lee et al., 2013).

TLR signalling cascades lead to the enhanced production of pro-inflammatory cytokines, such as IL1 $\beta$, TNF (tumour necrosis factor), IL8 (Rauta et al., 2014) and IFN molecules, which alert adaptive immune cells to an existing pathogen and mediate direct defence responses (Iwasaki and Medzhitov, 2004; Kawai and Akira, 2010). In addition, triggering TLRs can result in apoptosis (Salaun et al., 2007).

Exogenous IFNa up-regulated TLR7 mRNA expression in macrophages (Miettinen et al., 2001). It was found that a TLR7 ligands stimulator triggered the expression of ifna and $m x$; thus, it potentiated the antiviral activity in Atlantic salmon, Salmo salar L. (Kileng et al., 2008; Sun et al., 2009), induced the IFN response in salmonid leukocytes (Palti et al., 2010; Svingerud et al., 2012) and stimulated IFN and TNF secretions from peripheral blood mononuclear cells in rat (Hammerbeck et al., 2007).

Similarly, activation of TLR7 is required to produce imidazoquinoline-inducible IFN by macrophages (Hemmi et al., 2002). In addition, the TLR7/TLR8 agonist stimulated the production of Ifn, Il1 $\beta$ and Il 8 in rainbow trout leukocytes (Palti et al., 2010). These lead to T-helper1 (Th1) immune response and CD4+ T-cell activation, which is vital for the host's antiviral defence (Jault et al., 2004). 


\section{Cytokines and chemokines}

The immune system of fish contains both non-specific and specific mechanisms, and has cellular and humoral mechanisms to fight pathogens. Mononuclear phagocytes and Tlymphocytes from the non-specific and specific immunity pathways, respectively, are typically the major cell sources of the immune modulators, cytokines. Cytokines, are generally defined as interleukins, lymphokines, members of the TNF family and chemokines, based on the cells from which they are secreted, their functions and their targets (Alejo and Tafalla, 2011); they have a significant function in complement activation, chemotaxis, and pathogen opsonisation in the process of phagocytosis (Secombes et al., 2001; Salaun et al., 2007).

The earliest immune mediators released following virus infection are cytokines, which regulate the induction and maintenance of innate and acquired antiviral responses (Tortorella et al., 2000) and allow the clearance of viral infection (He et al., 2006). The pro-inflammatory cytokines produced by Th1 cells, IFN $\gamma$ and TNF $\alpha / \beta$, induce innate and cell-mediated responses against bacteria, fungi and viruses, resulting in their clearance, as well as having anti-tumour effects (Davidson et al., 1996; Micallef et al., 1996; Wan and Flavell, 2009; Choi et al., 2013; Gerber et al., 2013; Assani et al., 2014; Lai et al., 2014).

Many fish cytokines are identified, such as Il1 $\beta$ (Zou et al., 1999), Il2 (Bird et al., 2005a), Il4 (Li et al., 2007), Il6 (Bird et al., 2005b), Il8 (Lee et al., 2001), Il10 (Savan et al., 2003), Il11 (Wang et al., 2005), Il12 (Yoshiura et al., 2003), Il15 (Bei et al., 2006), Il17 (Gunimaladevi et al., 2006), Il18 (Zou et al., 2004a), Tnfa (Savan and Sakai, 2004), Ifn $\gamma$ (Zou et al., 2004b) and myxovirus resistance (Mx) (Staeheli et al., 1989).

\section{Interleukin 1 (ill)}

The IL1 family, one of the major IL families in fish and mammals, has four main members: IL1 $\alpha$, IL1 $\beta$, IL18 (interferon-gamma inducing factor) and IL1 receptor antagonist (IL1ra) (Dinarello, 1997; 1999; Mulero et al., 1999; Busfield et al., 2000; Smith et al., 2000; Pan et al., 2001). However, il1 $\beta$ is the most studied in relation to innate immunity in fish.

\section{Interleukin $1 \beta($ ill $\beta)$}

Il $1 \beta$ is well-characterized cytokine, plays an important role in cellular responses to immunological challenges, infection and inflammation. Macrophages are the primary source of Il1 $\beta$, although it is secreted by various other cell types including nature killer (NK) cells, B-cells, Langerhans cells of the skin, peripheral neutrophilic granulocytes, endothelial cells, fibroblasts and microglia cells (Huising et al., 2004; Tassakka and Sakai, 2004). Il1 $\beta$ is a key player in the defence against microorganism invasion and tissue injury and is able to induce immune responses by stimulating lymphocytes or by enhancing the release of other cytokines that can activate NK cells, macrophages and lymphocytes (Low et al., 2003).

In fish, ill $\beta$ is constitutively expressed in several tissues, such as spleen, head kidney and liver, and higher expression has been detected in the spleen (Tafalla et al., 2005; Lu et al., 2008). Moreover, upon administration with recombinant Il1 $\beta$, the systemic gene expression of ill $\beta$ was induced in rainbow trout, Oncorhynchus mykiss (Hong et al., 2003), yellowfin sea bream, Acanthopagrus latus (Jiang et al., 2008), orange-spotted grouper, Epinephelus coioides (Lu et al., 2008) and grass carp, Ctenopharyngodon idella (Bo et al., 2015). 
The mRNA level of $i l 1 \beta$ significantly increased in response to bacterial (Mohanty and Sahoo, 2010), viral (Tafalla et al., 2005) and parasitic (Bridle et al., 2006; Mladineo and Block, 2010) infections, indicating its main role as a member in immune system. Furthermore, in chronically stressed fish (Bermejo-Nogales et al., 2007), during the smolting of Atlantic salmon (Ingerslev et al., 2006), as well as in acute stress in common carp, Cyprinus carpio L. (Metz et al., 2006) there was an increase in the expression of pro-inflammatory cytokines $(i l 1 \beta, \operatorname{tnf} \alpha)$.

Even a change in the dietary components in hybrid tilapia (Zhang et al., 2014b) or the addition of oxytetracycline, formic and propionic acid/salt mixture to the feed of Nile tilapia (Reda et al., 2016) changed the expression of ill $\beta$ and disease resistance. Intraperitoneal injection of the common carp with the toxic material carbon tetrachloride $\left(\mathrm{CCl}_{4}\right)$ up-regulated the gene expressions of inflammatory cytokines, including $i l l \beta$ and tnfa (Jia et al., 2014).

\section{Tumour necrosis factor alpha (tnf $\alpha$ )}

TNF $\alpha$ was first identified in fish as a single copy gene in the stimulated leukocytes of the Japanese flounder, Paralychthys olivaceus (Hirono et al., 2000). TNF $\alpha$ is a central regulatory cytokine in antimicrobial and inflammatory responses (Grayfer et al., 2008). The treatment of Rhodococcus equi infected mice with antibodies against IFN $\gamma$ and TNF $\alpha$ increased the tissue colony counts. Thus, IFN $\gamma$ and TNF $\alpha$ are involved in cell-mediated immunity against bacterial infection (Nordmann et al., 1993). Furthermore, Tnfo has the ability to induce the gene expression of $i l 1 \beta$ and $i l 8$ (Zou et al., 2003).

TNF $\alpha$ is involved in viral (Purcell et al., 2004) and ectoparasitic (Saurabh et al., 2011) invasions. Moreover, the expression of tif could be considered for the assessment of fryrearing environment (Lam et al., 2011).

$\mathrm{TNF} \alpha$ stimulates the proliferation of trout leucocytes. TNF $\alpha$ and macrophage activating factor synergistically act on rainbow trout macrophages. This synergy causes elevation in respiratory burst activity in trout macrophages and this action is ablated after pre-incubation with neutralising mouse anti-TNFa IgG antibody (Hardie et al., 1994). $\mathrm{TNF} \alpha$ can enhance chemotactic responses and phagocytosis in a dose-dependent manner, induce nitric oxide production in primary macrophages, and prime respiratory burst in monocytes (Grayfer et al., 2008).

Tnfo is predominantly expressed in non-specific cytotoxic cells (NCCs) of tilapia (Praveen et al., 2006a). The pro-apoptotic effects of TNF $\alpha$ are mainly responsible for macrophage-mediated cytotoxicity (Goetz et al., 2004). Recombinant tilapia Tnfo is highly cytotoxic to mammalian cells (Praveen et al., 2006a), and the trout Tnf $\alpha$ markedly stimulated cytotoxicity in murine L929 cells (Qin et al., 2001). In other words, this cytotoxic effect may because TNF $\alpha$ has the ability to decrease telomerase activity and cause telomeric disturbances (shortening, fusions, and losses) and additional chromosomal aberrations (Beyne-Rauzy et al., 2004).

$\mathrm{TNF} \alpha$ plays an important role in regulation of the biosynthesis of steroid hormones (Yan et al., 1993; Zhao et al., 1996). There is possible reciprocal feedback among IL1 $\beta, T N F \alpha$ and testosterone. The basal secretion of testosterone in purified leydig cells and whole testis cells was stimulated by TNF and IL1 $\beta$ (Warren et al., 1990). In Nile tilapia, $\operatorname{tnf} \alpha$ expression showed an early up-regulation and late down-regulation upon treatment with MT (Abo-Al-Ela et al., 2017a). These give us an indication about the interaction between cytokines and sex hormones in fish, which may result in positive or negative action. 


\section{Chemokines}

Chemokines are a large multifunctional family of cytokines (Chemotactic cytokines) (Laing and Secombes, 2004a). They are a diverse group of small cytokines that can be divided into numerous families. Chemokines are structurally related and contain four invariant cysteine residues. Based on the arrangement of these cysteine residues, they are classified into four subfamilies: $\mathrm{CXC}(\alpha), \mathrm{CC}(\beta), \mathrm{C}(\gamma)$ and $\mathrm{CX} 3 \mathrm{C}(\delta)$ (Baggiolini, 1998; Murphy et al., 2000; Alejo and Tafalla, 2011). Furthermore, a new family of chemokines called CX, which includes five members, has been determined in zebrafish, Danio rerio (Nomiyama et al., 2008). Interestingly, some microorganisms (especially viruses) appear to have copies of chemokine genes, probably to confuse the immune system of the host (Laing and Secombes, 2004a), which in this way may protect themselves.

\section{CXC-chemokines}

The Cys-Xaa-Cys (CXC)-chemokines are a superfamily of the chemotactic cytokines that play a vital role in leucocyte chemotaxis; they are able to recruit various immune cells to infection sites (Kim et al., 2007; Liu et al., 2007), and they are substantial and selective mediators in leukocyte migration to secondary lymphoid organs and inflammatory sites (Vandercappellen et al., 2008). They have been categorized as key regulators of the immune defence, acting as a link between innate and adaptive responses (Alejo and Tafalla, 2011).

In vitro, an $\mathrm{CXC}$-chemokine significantly induces leukocyte recruitment, including granulocytes, lymphocytes, monocytes/macrophages and neutrophils; they have distinct effects on phagocyte activation; they increase respiratory burst activity; they induce a moderate increase in Il1 $\beta$; and they up-regulate the expression of a wide range of immune relevant genes, including ill $\beta$, ils, thf $\alpha$ and $m x$ (Li et al., 2012; van der Aa et al., 2012).

Additionally, CXC-chemokines play an essential role in hepatic injury, recovery and regeneration (Clarke et al., 2009). Macrophage-derived chemokines are capable of inducing both respiratory burst and the release of lysosomal enzyme from macrophages in mouse and enhancing the killing and phagocytic activities of macrophages against $E$. coli (Matsukawa et al., 2000).

$C X C$-chemokine is expressed in a basal manner and is found most noticeably in immune organs, such as the tissue and phagocytes of the anterior kidney and the spleen (Huising et al., 2003; Baoprasertkul et al., 2004). CXC-chemokine transcripts and proteins can show a marked increase and play vital roles in the immune response against bacterial (Baoprasertkul et al., 2004), viral (Li et al., 2012) and parasitic (Huising et al., 2003) infections. During the early stages of turbot embryo development after fertilization, a low expression level of $C X C$-chemokine was first detected at the somite stage. Interestingly, turbot chemokine expression was markedly and rapidly induced in the spleen, liver and head kidney as well as in turbot embryonic cells after challenge with Vibrio anguillarum (Liu et al., 2007).

Interleukin 8 (il8)

The first CXC-chemokine reported in fish was Il8 (Najakshin et al., 1999). The role of $\mathrm{ELR}^{+}$CXC-chemokines including Il8 (CXCL8) is to enhance the adherence of neutrophils to endothelial cells, followed by migration along a gradient of chemokines 
conjoined with matrix proteins and cell surfaces towards the inflammatory site (Laing and Secombes, 2004a). Il8 is a powerful chemoattractant to neutrophils, cytokinestimulated eosinophils, basophils and peripheral blood T-lymphocytes (White et al., 1989; Warringa et al., 1991; Baggiolini et al., 1994).

The recombinant Il8 induced migration of head kidney lymphocytes and peripheral blood leukocytes, promoted the proliferation of these cells in a dose-dependent manner, and up-regulated the expression of $i l 1 \beta$ and $i l 8$ in head kidney lymphocyte culture $(\mathrm{Hu}$ et al., 2011; Sun et al., 2011). Fish il8 is expressed in many tissues under normal condition and it is clearly up-regulated after bacteria, viral and external parasitic challenges (Tafalla et al., 2005; Covello et al., 2009; Ming et al., 2013).

\section{CC-chemokine}

CC-chemokines are a major subfamily of chemokines, and are essential members of the innate immune system ( $\mathrm{Hu}$ and Zhang, 2015); they provoke chemotaxis (recruitment, activation and adhesion) of various types of leukocytes under normal physiological and inflammatory conditions (He et al., 2004; Colobran et al., 2007; Peatman and Liu, 2007; Borza et al., 2010). They are also involved in normal developmental processes as well as the maintenance and organization of lymphoid organ architecture (He et al., 2004). They primarily target mononuclear cells rather than the neutrophils that mediate either homeostatic or pro-inflammatory mechanisms (Laing and Secombes, 2004a). CC-chemokines are involved in antibacterial and antiviral immune responses in fish (Su et al., 2012; Kim et al., 2013).

Nakharuthai et al. (2016) isolated a $C C$-chemokine in Nile tilapia that participate in early immune defences against pathogens such as bacteria, in which many tissues especially the spleen, liver and peripheral blood leukocytes express significantly higher transcript levels than controls. In vitro, recombinant CC-chemokine proteins efficiently stimulated phagocytic activity in Nile tilapia (Nakharuthai et al., 2016) and Japanese flounder (Kono et al., 2003).

The chemotactic activity of peripheral blood leucocytes was markedly evoked in response to stimulation by recombinant CC-chemokine protein (Khattiya et al., 2007; Zhang et al., 2008; Li et al., 2011). Moreover, in humans, CC-chemokines can activate macrophages to kill parasites by means of nitric oxide (Villalta et al., 1998). Interestingly, CC-chemokines were secreted following the stimulation of trout macrophage-like cells by recombinant TNFa (Laing and Secombes, 2004b), which indicates an interaction between several cytokines.

$C C$-chemokines are constitutively expressed in lymphoid-rich tissues, such as liver, head kidney, spleen, gill and peripheral blood leucocytes (Laing and Secombes, 2004b; Khattiya et al., 2007; Li et al., 2011; Su et al., 2012). Their expression was detected during the early developmental stages of the blunt snout bream, before hatching and at $62 \mathrm{~h}$ post fertilization, and were strongly induced and quickly up-regulated upon nitrite stress, supporting the possible existence of pro-inflammatory function (Zhang et al., 2014a). More recently, a set of $C C$-chemokine ligand genes have been identified and characterized from the channel catfish. Many of the identified $C C$-chemokines were significantly up-regulated following bacterial infection and hypoxia (Fu et al., 2017), supporting the possible effect of external environmental stress as hypoxia on immunerelated gene expression. 


\section{Interferon (ifn)}

Viral diseases are a serious pathogenic threat, and they have an important concern in the fish aquaculture industry (Langevin et al., 2013); thus, fish antiviral responses are the focus of research, especially on species that have commercial value. Innate defences can play a central role in fish resistance to viral infections (Ellis, 2001). The IFN family is a key component of innate and adaptive immunity (Schroder et al., 2004; Collet, 2014). The IFN system is a powerful and a rapid defence mechanism and a hallmark against viral (Samuel, 1991; Verrier et al., 2011) as well as bacterial (Schultz et al., 2004; Chen et al., 2010) and parasitic infections (Stolte et al., 2008) in vertebrates and fish; it is also involved in tumour control (Schroder et al., 2004).

IFN has the ability to inhibit the cellular replication and propagation of different viruses (Sadler and Williams, 2008; Collet, 2014). IFNs are divided into three subfamilies, type I, type II and type III, based on the relevant receptors they interact with and the immune responses initiated by them (Sadler and Williams, 2008; Zou and Secombes, 2011). Homologues of type I and type II Ifn have been found in many teleost fish species, including sea bass, Dicentrarchus labrax (Casani et al., 2009). IFNs recognise viral PAMPs via an array of PRRs (Pichlmair and Sousa, 2007; Kawai and Akira, 2009).

In mammals, IFN induces the pro-apoptotic genes that result in the destruction of infected cells (Chawla-Sarkar et al., 2003). The recombinant Ifn $\gamma$ of goldfish have been found to stimulate the respiratory burst responses of macrophages and neutrophils, and increase the nitric oxide production and the phagocytic responses of the macrophages (Grayfer and Belosevic, 2009).

\section{Myxovirus resistance $(m x)$}

The $M x$ gene was discovered for the first time in a strain of mice (A2G) that is resistant to influenza viruses type A and type B (Lindenmann, 1962). The first isolated fish Mx was in perch (Staeheli et al., 1989).

The Mx protein is rapidly accumulated in the cytoplasm or nucleus, and it selfassembles to form oligomers that interfere with virus replication (Lee and Vidal, 2002; Haller et al., 2007). Lin et al. (2005) found that, in Japanese flounder, the Mx protein is concentrated in the cell cytoplasm; however, in mouse, Mx accumulates in the cell nucleus and inhibits viruses that are known to replicate in that part of the cell (Haller et al., 2007). The possible antiviral mechanisms of Mx include blocking the transport of viral nucleocapsids, inhibition of viral RNA transcription or translation and targeting of viral elements, such as viral polymerase complex (Stranden et al., 1993; Kochs and Haller, 1999; Haller et al., 2007).

Constitutive expression of $m x$ was found in blood leukocytes, as well as the kidney, liver, spleen, heart, intestine, gills, muscle, brain and peritoneal cavity fluid of many fish species (Lee et al., 2000; Bergan and Robertsen, 2004; Tafalla et al., 2004). The IFN antiviral state is established by the up-regulation of antiviral proteins gene expression, including $m x$ (Jensen and Robertsen, 2002). Viral infection clearly induces $i l l \beta$, tnf $\alpha$ and $m x$ expression in a variety of immune tissues found in fish (Lee et al., 2000; Poisa-Beiro et al., 2008; Kim et al., 2009). On its own, the over-expression of the IFN-induced Mx protein can provide complete viral resistance against various viruses in fish (Larsen et al., 2004; Lester et al., 2012). 
Disruption of the $M x$ gene caused a repression of innate immunity against viruses and rapid death (Haller et al., 1998). Moreover, in Atlantic salmon, the stress that accompanies the smolting process alerted the basal transcript levels of $m x$ (Das et al., 2007).

\section{Immunoglobulin M (IgM)}

Immunoglobulin (Ig) genes encode a family of defence proteins known as antibodies. Antibodies are synthesised by B-cells, which undergo a complex series of somatic mutations and chromosomal rearrangements to generate antibodies with high specificity. IgM has a low molecular weight. Ig consists of two heavy chains and two light chains, linked together by disulphide bonds (Warr, 1995). The immune system in fish reported to contain four types of Ig: IgM, IgZ, IgD and IgT (Randelli et al., 2008).

IgM antibodies comprise the major component of the body antibodies, and it is the first category of antibodies generated during a primary antibody response. The IgM antibodies vary from other categories of antibodies in that they are mainly produced by B1 cells, with the apparent lack of stimulation by specific antigens. Most pathogens trigger a humoral immune response that results in an early increase in antigen-specific $\operatorname{IgM}$, followed by a more specific response of antigen-specific antibodies: IgA, IgG and IgE (such as IgT/Z and IgD in fish) (Boes, 2000).

The first appearance of $\operatorname{IgM}$ in lymphocytes differs considerably among fish species. In channel catfish and rainbow trout, the first appearance of surface IgM occurs about one week after hatching. The maternal antibody that is transmitted to eggs and embryos has been detected in several species, including tilapia, carp, plaice, sea bass and salmon (Magnadottir et al., 2005). The IgM-like protein levels decreased gradually as yolk was absorbed (12 days post-hatching, dph) during pre-larval stages of tilapia. After yolk utilisation, the feeding and free swimming begins. About this time, the IgM-like protein drops to its lowest levels, but it increases rapidly during the post-larval stages (Takemura, 1993). IgM transcripts were also detectable at $5 \mathrm{dph}$ in the striped trumpeters, Latris lineata (Covello et al., 2013). However, in chum salmon (Oncorhynchus keta), the serum IgM concentrations remained at a low level until 40 $\mathrm{dph}$, and then they increased rapidly at $48 \mathrm{dph}$ (Nagae et al., 1993).

In teleost fishes, $\operatorname{IgM}$ is the only member of the specific humoral defence system that is modulated by aquatic environment factors, such as water temperature, salinity and suspended solids (Dominguez et al., 2004). In particular, the levels of plasma IgM were decreased in cold-treated and stressed tilapia (Chen et al., 2002). Hypoxia significantly suppressed $\operatorname{Ig} M$, ill $\beta$ gene expression, and it also delayed antibody production in infected Nile tilapia (Gallage et al., 2016).

$\operatorname{IgM}$ secretion and expression can be altered in response to chemicals or hormones. In Nile tilapia, the organochlorine insecticide, endosulfan, led to a significant increase in the secretion of IgM; consequently, it may encourage the production of autoantibodies and the development of autoimmune problems after exposure to infection (Tellez-Banuelos et al., 2010), and after short treatment with MT (Abo-AlEla et al., 2017b). Furthermore, common carp, exposed to chlorpyrifos (an organophosphate pesticide that is widely used in agricultural) for 7 days, showed an augmentation in IgM expression at the earlier stage of exposure, but it was reduced at the later stage (Li et al., 2013). 


\section{Vitellogenin (vtg)}

The egg-yolk precursor, vitellogenin (Vtg), acts as a nutrient source for developing embryos, and it also participates in innate immunity (Zhang et al., 2011; Lu et al., 2012). Vtg is a multivalent pattern recognition receptor that has the ability to recognise pathogens via interaction with PAMPs ( $\mathrm{Li}$ et al., 2008; Li et al., 2009), and it has hemagglutinating and antimicrobial activities (Zhang et al., 2005; Liu et al., 2009). It is able to bind virus, lipopolysaccharide, peptidoglycan, lipoteichoic acid and glucan. It can also act as a bactericidal molecule capable of binding to bacteria, inhibiting bacterial activities and damaging bacterial cell walls (Zhang et al., 2011). Vtg is an opsonin that is able to enhance phagocytosis; it significantly up-regulates the expression of pro-inflammatory cytokine genes, $i l 1 \beta$ and $t n f \alpha$ (Liu et al., 2011a). It has been reported that Atlantic salmon serum Vtg can neutralise the action of the infectious pancreatic necrosis virus (Garcia et al., 2010). All of these elucidate that Vtg is an immune-relevant protein involved in the host defence process against microbes, including bacteria and viruses (Zhang et al., 2011).

In zebrafish larvae, vtg gene transcription was detected during the early stages of development, 7 days after fertilisation (Wang et al., 2011). The treatment of mature female Nile tilapia with high levels of MT resulted in a pronounced decrease in the plasma Vtg levels (Lazier et al., 1996). Hepatic Vtg levels were significantly decreased in female medaka (Oryzias latipes) treated with MT at concentrations of $380 \mathrm{ng} / \mathrm{L}$ and $188 \mathrm{ng} / \mathrm{L}$ for 3 weeks (Kang et al., 2008).

\section{Cellular apoptosis susceptibility (cas)}

Apoptosis is the process of cellular death; it is considerably different from necrosis, which is recognised as the classic system of cell death (Cotter et al., 1990). Apoptosis is an important biological process that destroys virus-infected cells, and it is presumed to be an innate response to counteract viral infection (Wrzesien-Kus et al., 2004). Replicating viruses may directly induce suicide of the host cell or promote recognition by natural killer cells and cytolytic T-cells, and these immune effector cells induce apoptosis (Tortorella et al., 2000).

Several genes control the apoptosis process; for example, cellular apoptosis susceptibility (cas). CAS is a microtubule-associated protein that links with microtubules and mitotic spindles (Brinkmann et al., 1995; Scherf et al., 1996). Mitotic spindles are cellular organelles, which play a role in chromosome segregation during cell division (Kuriyama and Nislow, 1992). CAS is associated with cell proliferation and apoptosis (Brinkmann, 1998) and in protection against apoptotic cell death (Praveen et al., 2006b). The Cas protein is important in the regulation of teleost immune functions. NCCs are one of the cellular sources for cas transcription in tilapia fish. The up-regulated expression of cas, following exposure to stress-activated serum, indicates the involvement of cas as a protector against apoptotic cell death (Praveen et al., 2006b). Furthermore, NCCs in tilapia treated with recombinant tilapia Tnfo revealed an up-regulation of cas expression, indicating that cas may act as a mediator for protective effects of Tnf $\alpha$ on NCC (Praveen et al., 2006b).

In many cases, apoptosis can harm virus replication. Therefore, viruses may protect themselves through the inhibition of proteins implicated in the apoptotic process ( $\mathrm{He}$ et al., 2006). 


\section{Glutathione S-transferase (gst)}

The glutathione $S$-transferases (GSTs), a multifunctional family of enzymes, are a natural defence system that catalyse the conjugation of many harmful electrophiles with reduced glutathione through formation of a thioether bond (Scott et al., 1992). GST, a main player in the detoxification system and in antioxidant defence (Frova, 2006; Puerto et al., 2011), plays a vital role in immune responses (Wang et al., 2013). Its expression is greatly changed in response to bacterial challenges in the Mediterranean mussel, Mytilus galloprovincialis (Wang et al., 2013), and also was in line with the expression of immune-related genes in Nile tilapia (Abo-Al-Ela et al., 2017a).

Interestingly, the treatment of sertoli cells with $\mathrm{TNF} \alpha$ induced a decrease in basal GST $\alpha$ transcription levels in a dose-dependent manner. TNF $\alpha$ also inhibited the hormone testosterone-stimulated GSTa expression (Benbrahim-Tallaa et al., 2002), which give another example for the cross-link between GST $\alpha$ and immune members.

Some GSTs possess peroxidase activity against organic peroxides, thus they can protect from lipid peroxidation, while other specific enzymes can reduce peroxidised DNA, so they may be involved in DNA repair (Scott et al., 1992). In a previous study, tilapia were subjected to cadmium chloride. Significant increases were evident in the detoxification enzymes of liver and kidney, including Gst from the seventh day continuously until the fifteenth day, and then reduced slightly on the thirtieth day of cadmium stress (Basha and Rani, 2003). To this end, oxidative stress could badly affect the immune parameters.

\section{Conclusive remarks}

The synergism of the immune system is finely tuned in such a way that each player in this orchestra cooperates to protect the living body. In the last few years, there have been great advances in the field of fish immunology, although diseases continue to cause economic losses to industry's aquaculture sector. This field of study has prompted researchers to investigate the role, function and molecular characterization of other genes that may participate in the immune system. Many of the mentioned references support the theory of the powerful link and interaction between the immune system and body status (hormones, treatment, environment, etc.). However, it will be necessary to gain a deep understanding of the mechanism underlying gene-gene interactions and the molecular bases of immune functions.

\section{REFERENCES}

[1] Abo-Al-Ela, H. G. (2018): Hormones and fish monosex farming: A spotlight on immunity. - Fish \& Shellfish Immunology 72: 23-30.

[2] Abo-Al-Ela, H. G., El-Nahas, A. F., Mahmoud, S., Ibrahim, E. M. (2017a): The extent to which immunity, apoptosis and detoxification gene expression interact with 17 alphamethyltestosterone. - Fish \& Shellfish Immunology 60: 289-298.

[3] Abo-Al-Ela, H. G., El-Nahas, A. F., Mahmoud, S., Ibrahim, E. M. (2017b): Vitamin C modulates the immunotoxic effect of $17 \alpha$-methyltestosterone in Nile tilapia. Biochemistry 56(14): 2042-2050.

[4] Akira, S., Takeda, K., Kaisho, T. (2001): Toll-like receptors: critical proteins linking innate and acquired immunity. - Nature Immunology 2(8): 675-680. 
[5] Alejo, A., Tafalla, C. (2011): Chemokines in teleost fish species. - Developmental and Comparative Immunology 35(12): 1215-1222.

[6] Alvarez-Pellitero, P. (2008): Fish immunity and parasite infections: from innate immunity to immunoprophylactic prospects. - Veterinary Immunology and Immunopathology 126(3-4): 171-198.

[7] Assani, K., Tazi, M. F., Amer, A. O., Kopp, B. T. (2014): IFN- $\gamma$ stimulates autophagymediated clearance of Burkholderia cenocepacia in human cystic fibrosis macrophages. Plos One 9(5): e96681.

[8] Baggiolini, M. (1998): Chemokines and leukocyte traffic. - Nature 392(6676): 565-568.

[9] Baggiolini, M., Dewald, B., Moser, B. (1994): Interleukin-8 and related chemotactic cytokines - Cxc and Cc chemokines. - Advances in Immunology 55: 97-179.

[10] Baoprasertkul, P., Peatman, E., Chen, L. Q., He, C. B., Kucuktas, H., Li, P., Simmons, M., Liu, Z. J. (2004): Sequence analysis and expression of a $C X C$ chemokine in resistant and susceptible catfish after infection of Edwardsiella ictaluri. - Developmental and Comparative Immunology 28(7-8): 769-780.

[11] Basha, P. S., Rani, A. U. (2003): Cadmium-induced antioxidant defense mechanism in freshwater teleost Oreochromis mossambicus (Tilapia). - Ecotoxicology and Environmental Safety 56(2): 218-221.

[12] Baum, A., Garcia-Sastre, A. (2010): Induction of type I interferon by RNA viruses: cellular receptors and their substrates. - Amino Acids 38(5): 1283-1299.

[13] Bei, J. X., Suetake, H., Araki, K., Kikuchi, K., Yoshiura, Y., Lin, H. R., Suzuki, Y. (2006): Two interleukin (IL)-15 homologues in fish from two distinct origins. Molecular Immunology 43(7): 860-869.

[14] Benbrahim-Tallaa, L., Boussouar, F., Rey, C., Benahmed, M. (2002): Tumor necrosis factor-alpha inhibits glutathione $S$-transferase-alpha expression in cultured porcine Sertoli cells. - Journal of Endocrinology 175(3): 803-812.

[15] Bergan, V., Robertsen, B. (2004): Characterization of Atlantic halibut (Hippoglossus hippoglossus) Mx protein expression. - Developmental and Comparative Immunology 28(10): 1037-1047.

[16] Bermejo-Nogales, A., Saera-Vila, A., Calduch-Giner, J. A., Navarro, J. C., SitjaBobadilla, A., Perez-Sanchez, J. (2007): Differential metabolic and gene expression profile of juvenile common dentex (Dentex dentex L.) and gilthead sea bream (Sparus aurata L.) in relation to redox homeostasis. - Aquaculture 267(1-4): 213-224.

[17] Beyne-Rauzy, O., Recher, C., Dastugue, N., Demur, C., Pottier, G., Laurent, G., Sabatier, L., Mansat-De Mas, V. (2004): Tumor necrosis factor alpha induces senescence and chromosomal instability in human leukemic cells. - Oncogene 23(45): 7507-7516.

[18] Bird, S., Zou, J., Kono, T., Sakai, M., Dijkstra, J. M., Secombes, C. (2005a): Characterisation and expression analysis of interleukin $2(I L-2)$ and $I L-21$ homologues in the Japanese pufferfish, Fugu rubripes, following their discovery by synteny. Immunogenetics 56(12): 909-923.

[19] Bird, S., Zou, J., Savan, R., Kono, T., Sakai, M., Woo, J., Secombes, C. (2005b): Characterisation and expression analysis of an interleukin 6 homologue in the Japanese pufferfish, Fugu rubripes. - Developmental and Comparative Immunology 29(9): 775789.

[20] Bo, Y. X., Song, X. H., Wu, K., Hu, B., Sun, B. Y., Liu, Z. J., Fu, J. G. (2015): Characterization of interleukin-1 beta as a proinflammatory cytokine in grass carp (Ctenopharyngodon idella). - Fish \& Shellfish Immunology 46(2): 584-595.

[21] Boes, M. (2000): Role of natural and immune IgM antibodies in immune responses. Molecular Immunology 37(18): 1141-1149.

[22] Borza, T., Stone, C., Rise, M. L., Bowman, S., Johnson, S. C. (2010): Atlantic cod (Gadus morhua) CC chemokines: Diversity and expression analysis. - Developmental and Comparative Immunology 34(8): 904-913. 
[23] Bridle, A. R., Morrison, R. N., Cunningham, P. M. C., Nowak, B. F. (2006): Quantitation of immune response gene expression and cellular localisation of interleukin-1 beta mRNA in Atlantic salmon, Salmo salar L., affected by amoebic gill disease (AGD). Veterinary Immunology and Immunopathology 114(1-2): 121-134.

[24] Brinkmann, U. (1998): CAS, the human homologue of the yeast chromosome-segregation gene CSE1, in proliferation, apoptosis, and cancer. - American Journal of Human Genetics 62(3): 509-513.

[25] Brinkmann, U., Brinkmann, E., Pastan, I. (1995): Expression cloning of cDNA that render cancer-cells resistant to Pseudomonas and diphtheria-toxin and Immunotoxins. Molecular Medicine 1(2): 206-216.

[26] Busfield, S. J., Comrack, C. A., Yu, G., Chickering, T. W., Smutko, J. S., Zhou, H., Leiby, K. R., Holmgren, L. M., Gearing, D. P., Pan, Y. (2000): Identification and gene organization of three novel members of the $I L-1$ family on human chromosome 2. Genomics 66(2): 213-216.

[27] Casani, D., Randelli, E., Costantini, S., Facchiano, A. M., Zou, J., Martin, S., Secombes, C. J., Scapigliati, G., Buonocore, F. (2009): Molecular characterisation and structural analysis of an interferon homologue in sea bass (Dicentrarchus labrax L.). - Molecular Immunology 46(5): 943-952.

[28] Chawla-Sarkar, M., Lindner, D. J., Liu, Y. F., Williams, B., Sen, G. C., Silverman, R. H., Borden, E. C. (2003): Apoptosis and interferons: Role of interferon-stimulated genes as mediators of apoptosis. - Apoptosis 8(3): 237-249.

[29] Chen, W. H., Sun, L. T., Tsai, C. L., Song, Y. L., Chang, C. F. (2002): Cold-stress induced the modulation of catecholamines, cortisol, immunoglobulin $\mathrm{M}$, and leukocyte phagocytosis in tilapia. - General and Comparative Endocrinology 126(1): 90-100.

[30] Chen, W. Q., Xu, Q. Q., Chang, M. X., Zou, J., Secombes, C. J., Peng, K. M., Nie, P. (2010): Molecular characterization and expression analysis of the IFN-gamma related gene (IFN-gamma rel) in grass carp Ctenopharyngodon idella. - Veterinary Immunology and Immunopathology 134(3-4): 199-207.

[31] Choi, I. K., Li, Y., Oh, E., Kim, J., Yun, C. O. (2013): Oncolytic adenovirus expressing IL-23 and p35 Elicits IFN- $\gamma$ - and TNF- $\alpha$-co-producing $\mathrm{T}$ Cell-mediated antitumor immunity. - Plos One 8(7).

[32] Clarke, C. N., Kuboki, S., Tevar, A., Lentsch, A. B., Edwards, M. (2009): CXC chemokines play a critical role in liver injury, recovery, and regeneration. - American Journal of Surgery 198(3): 415-419.

[33] Collet, B. (2014): Innate immune responses of salmonid fish to viral infections. Developmental and Comparative Immunology 43(2): 160-173.

[34] Colobran, R., Pujol-Borrell, R., Armengol, M. P., Juan, M. (2007): The chemokine network. I. How the genomic organization of chemokines contains clues for deciphering their functional complexity. - Clinical and Experimental Immunology 148(2): 208-217.

[35] Cotter, T. G., Lennon, S. V., Glynn, J. G., Martin, S. J. (1990): Cell death via apoptosis and its relationship to growth, development and differentiation of both tumor and normal cells. - Anticancer Research 10(5A): 1153-1159.

[36] Covello, J. M., Bird, S., Morrison, R. N., Battaglene, S. C., Secombes, C. J., Nowak, B. F. (2009): Cloning and expression analysis of three striped trumpeter (Latris lineata) proinflammatory cytokines, TNF-alpha, IL-1 beta and $I L-8$, in response to infection by the ectoparasitic, Chondracanthus goldsmidi. - Fish \& Shellfish Immunology 26(5): 773786.

[37] Covello, J. M., Bird, S., Morrison, R. N., Bridle, A. R., Battaglene, S. C., Secombes, C. J., Nowak, B. F. (2013): Isolation of $R A G-1$ and $I g M$ transcripts from the striped trumpeter (Latris lineata), and their expression as markers for development of the adaptive immune response. - Fish \& Shellfish Immunology 34(3): 778-788. 
[38] Das, B. K., Collet, B., Snow, M., Ellis, A. E. (2007): Expression of interferon type I and II, $M x$ and gamma IP genes in the kidney of Atlantic salmon, Salmo salar, is induced during smolting. - Fish \& Shellfish Immunology 23(3): 514-520.

[39] Davidson, N. J., Leach, M. W., Fort, M. M., Thompson-Snipes, L., Kuhn, R., Muller, W., Berg, D. J., Rennick, D. M. (1996): T helper cell 1-type CD4(+) T cells, but not B cells, mediate colitis in interleukin 10-deficient mice. - Journal of Experimental Medicine 184(1): 241-251.

[40] Dinarello, C. A. (1997): Interleukin-1. - Cytokine \& Growth Factor Reviews 8(4): 253265.

[41] Dinarello, C. A. (1999): Interleukin-18. - Methods: A Companion to Methods in Enzymology 19(1): 121-132.

[42] Dominguez, M., Takemura, A., Tsuchiya, M., Nakamura, S. (2004): Impact of different environmental factors on the circulating immunoglobulin levels in the Nile tilapia, Oreochromis niloticus. - Aquaculture 241(1-4): 491-500.

[43] Ellis, A. E. (2001): Innate host defense mechanisms of fish against viruses and bacteria. Developmental and Comparative Immunology 25(8-9): 827-839.

[44] Frova, C. (2006): Glutathione transferases in the genomics era: New insights and perspectives. - Biomolecular Engineering 23(4): 149-169.

[45] Fu, Q., Yang, Y., Li, C., Zeng, Q., Zhou, T., Li, N., Liu, Y., Li, Y., Wang, X., Liu, S., Li, D., Liu, Z. (2017): The chemokinome superfamily: II. The 64 CC chemokines in channel catfish and their involvement in disease and hypoxia responses. - Developmental and Comparative Immunology 73: 97-108.

[46] Gallage, S., Katagiri, T., Endo, M., Futami, K., Endo, M., Maita, M. (2016): Influence of moderate hypoxia on vaccine efficacy against Vibrio anguillarum in Oreochromis niloticus (Nile tilapia). - Fish \& Shellfish Immunology 51: 271-281.

[47] Garcia, J., Munro, E. S., Monte, M. M., Fourrier, M. C. S., Whitelaw, J., Smail, D. A., Ellis, A. E. (2010): Atlantic salmon (Salmo salar L.) serum vitellogenin neutralises infectivity of infectious pancreatic necrosis virus (IPNV). - Fish \& Shellfish Immunology 29(2): 293-297.

[48] Gerber, S. A., Sedlacek, A. L., Cron, K. R., Murphy, S. P., Frelinger, J. G., Lord, E. M. (2013): IFN-gamma mediates the antitumor effects of radiation therapy in a murine colon tumor. - American Journal of Pathology 182(6): 2345-2354.

[49] Goetz, F. W., Planas, J. V., MacKenzie, S. (2004): Tumor necrosis factors. Developmental and Comparative Immunology 28(5): 487-497.

[50] Grayfer, L., Belosevic, M. (2009): Molecular characterization, expression and functional analysis of goldfish (Carassius aurutus L.) interferon gamma. - Developmental and Comparative Immunology 33(2): 235-246.

[51] Grayfer, L., Walsh, J. G., Belosevic, M. (2008): Characterization and functional analysis of goldfish (Carassius auratus L.) tumor necrosis factor-alpha. - Developmental and Comparative Immunology 32(5): 532-543.

[52] Gunimaladevi, I., Savan, R., Sakai, M. (2006): Identification, cloning and characterization of interleukin-17 and its family from zebrafish. - Fish \& Shellfish Immunology 21(4): 393-403.

[53] Haller, O., Frese, M., Kochs, G. (1998): Mx proteins: mediators of innate resistance to RNA viruses. - Revue Scientifique Et Technique De L Office International Des Epizooties 17(1): 220-230.

[54] Haller, O., Staeheli, P., Kochs, G. (2007): Interferon-induced Mx proteins in antiviral host defense. - Biochimie 89(6-7): 812-818.

[55] Hammerbeck, D. M., Burleson, G. R., Schuller, C. J., Vasilakos, J. P., Tomai, M., Egging, E., Cochran, F. R., Woulfe, S., Miller, R. L. (2007): Administration of a dual toll-like receptor 7 and toll-like receptor 8 agonist protects against influenza in rats. Antiviral Research 73(1): 1-11. 
[56] Hardie, L. J., Chappell, L. H., Secombes, C. J. (1994): Human tumor necrosis factor alpha influences rainbow trout Oncorhynchus mykiss leucocyte responses. - Veterinary Immunology and Immunopathology 40(1): 73-84.

[57] He, C. B., Peatman, E., Baoprasertkul, P., Kucuktas, H., Liu, Z. J. (2004): Multiple CC chemokines in channel catfish and blue catfish as revealed by analysis of expressed sequence tags. - Immunogenetics 56(5): 379-387.

[58] He, W., Yin, Z. X., Li, Y., Huo, W. L., Guan, H. J., Weng, S. P., Chan, S. M., He, J. G. (2006): Differential gene expression profile in spleen of mandarin fish Siniperca chuatsi infected with ISKNV, derived from suppression subtractive hybridization. - Diseases of Aquatic Organisms 73(2): 113-122.

[59] Hemmi, H., Kaisho, T., Takeuchi, O., Sato, S., Sanjo, H., Hoshino, K., Horiuchi, T., Tomizawa, H., Takeda, K., Akira, S. (2002): Small anti-viral compounds activate immune cells via the TLR7 MyD88-dependent signaling pathway. - Nature Immunology 3(2): 196-200.

[60] Hirono, I., Nam, B. H., Kurobe, T., Aoki, T. (2000): Molecular cloning, characterization, and expression of TNF cDNA and gene from Japanese flounder Paralychthys olivaceus. Journal of Immunology 165(8): 4423-4427.

[61] Hong, S. H., Peddie, S., Campos-Perez, J. J., Zou, J., Secombes, C. J. (2003): The effect of intraperitoneally administered recombinant IL-1 beta on immune parameters and resistance to Aeromonas salmonicida in the rainbow trout (Oncorhynchus mykiss). Developmental and Comparative Immunology 27(9): 801-812.

[62] Hu, Y. H., Chen, L., Sun, L. (2011): CXCL8 of Scophthalmus maximus: Expression, biological activity and immunoregulatory effect. - Developmental and Comparative Immunology 35(10): 1030-1037.

[63] Hu, Y. H., Zhang, J. (2015): CsCCL17, a CC chemokine of Cynoglossus semilaevis, induces leukocyte trafficking and promotes immune defense against viral infection. Fish \& Shellfish Immunology 45(2): 771-779.

[64] Huising, M. O., Stolte, E., Flik, G., Savelkoul, H. F. J., Verburg-van Kemenade, B. M. L. (2003): CXC chemokines and leukocyte chemotaxis in common carp (Cyprinus carpio L.). - Developmental and Comparative Immunology 27(10): 875-888.

[65] Huising, M. O., Stet, R. J. M., Savelkoul, H. F. J., Verburg-van Kemenade, B. M. L. (2004): The molecular evolution of the interleukin-1 family of cytokines; IL-18 in teleost fish. - Developmental and Comparative Immunology 28(5): 395-413.

[66] Ingerslev, H. C., Cunningham, C., Wergeland, H. I. (2006): Cloning and expression of TNF-alpha, IL-1 beta and COX-2 in an anadromous and landlocked strain of Atlantic salmon (Salmo salar L.) during the smolting period. - Fish \& Shellfish Immunology 20(4): 450-461.

[67] Iwasaki, A., Medzhitov, R. (2004): Toll-like receptor control of the adaptive immune responses. - Nature Immunology 5(10): 987-995.

[68] Janeway, C. A., Medzhitov, R. (2002): Innate immune recognition. - Annual Review of Immunology 20: 197-216.

[69] Jault, C., Pichon, L., Chluba, J. (2004): Toll-like receptor gene family and TIR-domain adapters in Danio rerio. - Molecular Immunology 40(11): 759-771.

[70] Jensen, I., Robertsen, B. (2002): Effect of double-stranded RNA and interferon on the antiviral activity of Atlantic salmon cells against infectious salmon anemia virus and infectious pancreatic necrosis virus. - Fish \& Shellfish Immunology 13(3): 221-241.

[71] Jia, R., Cao, L. P., Du, J. L., Wang, J. H., Liu, Y. J., Jeney, G., Xu, P., Yin, G. J. (2014): Effects of carbon tetrachloride on oxidative stress, inflammatory response and hepatocyte apoptosis in common carp (Cyprinus carpio). - Aquatic Toxicology 152: 11-19.

[72] Jiang, S. G., Zhang, D. C., Li, J. Z., Liu, Z. X. (2008): Molecular characterization, recombinant expression and bioactivity analysis of the interleukin-1 beta from the yellowfin sea bream, Acanthopagrus latus (Houttuyn). - Fish \& Shellfish Immunology 24(3): 323-336. 
[73] Kang, I. J., Yokota, H., Oshima, Y., Tsuruda, Y., Shimasaki, Y., Honjo, T. (2008): The effects of methyltestosterone on the sexual development and reproduction of adult medaka (Oryzias latipes). - Aquatic Toxicology 87(1): 37-46.

[74] Kawai, T., Akira, S. (2009): The roles of TLRs, RLRs and NLRs in pathogen recognition. - International Immunology 21(4): 317-337.

[75] Kawai, T., Akira, S. (2010): The role of pattern-recognition receptors in innate immunity: update on toll-like receptors. - Nature Immunology 11(5): 373-384.

[76] Kawai, T., Sato, S., Ishii, K. J., Coban, C., Hemmi, H., Yamamoto, M., Terai, K., Matsuda, M., Inoue, J., Uematsu, S., Takeuchi, O., Akira, S. (2004): Interferon-alpha induction through toll-like receptors involves a direct interaction of IRF7 with MyD88 and TRAF6. - Nature Immunology 5(10): 1061-1068.

[77] Khattiya, R., Kondo, H., Hirono, I., Aoki, T. (2007): Cloning, expression and functional analysis of a novel-chemokine gene of Japanese flounder, Paralichthys olivaceus, containing two additional cysteines and an extra fourth exon. - Fish \& Shellfish Immunology 22(6): 651-662.

[78] Kileng, O., Albuquerque, A., Robertsen, B. (2008): Induction of interferon system genes in Atlantic salmon by the imidazoquinoline S-27609, a ligand for toll-like receptor 7. Fish \& Shellfish Immunology 24(5): 514-522.

[79] Kim, H. J., Yasuike, M., Kondo, H., Hirono, I., Aoki, T. (2007): Molecular characterization and gene expression of a CXC chemokine gene from Japanese flounder Paralichthys olivaceus. - Fish \& Shellfish Immunology 23(6): 1275-1284.

[80] Kim, J. W., Kim, E. G., Kim, D. H., Shim, S. H., Park, C. I. (2013): Molecular identification and expression analysis of the $C C$ chemokine gene in rock bream (Oplegnathus fasciatus) and the biological activity of the recombinant protein. - Fish \& Shellfish Immunology 34(3): 892-901.

[81] Kim, Y. S., Ke, F., Zhang, Q. Y. (2009): Effect of beta-glucan on activity of antioxidant enzymes and $M x$ gene expression in virus infected grass carp. - Fish \& Shellfish Immunology 27(2): 336-340.

[82] Kochs, G., Haller, O. (1999): Interferon-induced human MxA GTPase blocks nuclear import of Thogoto virus nucleocapsids. - Proceedings of the National Academy of Sciences of the United States of America 96(5): 2082-2086.

[83] Kono, T., Kusuda, R., Kawahara, E., Sakai, M. (2003): The analysis of immune responses of a novel CC-chemokine gene from Japanese flounder Paralichthys olivaceus. - Vaccine 21(5-6): 446-457.

[84] Kumar, H., Kawai, T., Akira, S. (2011): Pathogen recognition by the innate immune system. - International Reviews of Immunology 30(1): 16-34.

[85] Kuriyama, R., Nislow, C. (1992): Molecular-components of the mitotic spindle. Bioessays 14(2): 81-88.

[86] Lai, R., Jeyanathan, M., Shaler, C. R., Damjanovic, D., Khera, A., Horvath, C., Ashkar, A. A., Xing, Z. (2014): Restoration of innate immune activation accelerates Th1-cell priming and protection following pulmonary mycobacterial infection. - European Journal of Immunology 44(5): 1375-1386.

[87] Laing, K. J., Secombes, C. J. (2004a): Chemokines. - Developmental and Comparative Immunology 28(5): 443-460.

[88] Laing, K. J., Secombes, C. J. (2004b): Trout CC chemokines: comparison of their sequences and expression patterns. - Molecular Immunology 41(8): 793-808.

[89] Lam, F. W. S., Wu, S. Y., Lin, S. J., Lin, C. C., Chen, Y. M., Wang, H. C., Chen, T. Y., Lin, H. T., Lin, J. H. Y. (2011): The expression of two novel orange-spotted grouper (Epinephelus coioides) TNF genes in peripheral blood leukocytes, various organs, and fish larvae. - Fish \& Shellfish Immunology 30(2): 618-629.

[90] Langevin, C., Aleksejeva, E., Passoni, G., Palha, N., Levraud, J. P., Boudinot, P. (2013): The antiviral innate immune response in fish: Evolution and conservation of the IFN system. - Journal of Molecular Biology 425(24): 4904-4920. 
[91] Larsen, R., Rokenes, T. P., Robertsen, B. (2004): Inhibition of infectious pancreatic necrosis virus replication by Atlantic salmon Mx1 protein. - Journal of Virology 78(15): 7938-7944.

[92] Lazier, C. B., Langley, S., Ramsey, N. B., Wright, J. M. (1996): Androgen inhibition of vitellogenin gene expression in tilapia (Oreochromis niloticus). - General and Comparative Endocrinology 104(3): 321-329.

[93] Lee, E. Y., Park, H. H., Kim, Y. T., Choi, T. J. (2001): Cloning and sequence analysis of the interleukin-8 gene from flounder (Paralichthys olivaceous). - Gene 274(1-2): 237243.

[94] Lee, J. Y., Hirono, I., Aoki, T. (2000): Cloning and analysis of expression of Mx cDNA in Japanese flounder, Paralichthys olivaceus. - Developmental and Comparative Immunology 24(4): 407-415.

[95] Lee, P. T., Zou, J., Holland, J. W., Martin, S. A. M., Kanellos, T., Secombes, C. J. (2013): Identification and characterization of TLR7, TLR8a2, TLR8b1 and TLR8b2 genes in Atlantic salmon (Salmo salar). - Developmental and Comparative Immunology 41(2): 295-305.

[96] Lee, S. H., Vidal, S. M. (2002): Functional diversity of Mx proteins: Variations on a theme of host resistance to infection. - Genome Research 12(4): 527-530.

[97] Lester, K., Hall, M., Urquhart, K., Gahlawat, S., Collet, B. (2012): Development of an in vitro system to measure the sensitivity to the antiviral $\mathrm{Mx}$ protein of fish viruses. Journal of Virological Methods 182(1-2): 1-8.

[98] Li, J. H., Shao, J. Z., Xiang, L. X., Wen, Y. (2007): Cloning, characterization and expression analysis of pufferfish interleukin-4 cDNA: The first evidence of Th2-type cytokine in fish. - Molecular Immunology 44(8): 2078-2086.

[99] Li, X. Y., Liu, L., Zhang, Y. N., Fang, Q., Li, Y. Y., Li, Y. L. (2013): Toxic effects of chlorpyrifos on lysozyme activities, the contents of complement C3 and IgM, and IgM and complement $\mathrm{C} 3$ expressions in common carp (Cyprinus carpio L.). - Chemosphere 93(2): 428-433.

[100] Li, Y. X., Sun, J. S., Sun, L. (2011): An inflammatory CC chemokine of Cynoglossus semilaevis is involved in immune defense against bacterial infection. - Fish \& Shellfish Immunology 31(3): 446-452.

[101] Li, Y. X., Hu, Y. H., Sun, J. S., Sun, L. (2012): CsCXCe1: A novel Cynoglossus semilaevis CXC chemokine that functions as a chemoattractant and an immunomodulator for peripheral blood leukocytes. - Developmental and Comparative Immunology 37(1): 55-64.

[102] Li, Z. J., Zhang, S. C., Liu, Q. H. (2008): Vitellogenin functions as a multivalent pattern recognition receptor with an opsonic activity. - Plos One 3(4): e1940.

[103] Li, Z. J., Zhang, S. C., Zhang, J., Liu, M., Liu, Z. H. (2009): Vitellogenin is a cidal factor capable of killing bacteria via interaction with lipopolysaccharide and lipoteichoic acid. Molecular Immunology 46(16): 3232-3239.

[104] Lin, O. E., Ohira, T., Hirono, I., Saito-Taki, T., Aoki, T. (2005): Immunoanalysis of antiviral Mx protein expression in Japanese flounder (Paralichthys olivaceus) cells. Developmental and Comparative Immunology 29(5): 443-455.

[105] Lindenmann, J. (1962): Resistance of mice to mouse-adapted influenza a virus. Virology 16(2): 203-204.

[106] Liu, M., Pan, J. L., Ji, H. F., Zhao, B. S., Zhang, S. C. (2011a): Vitellogenin mediates phagocytosis through interaction with Fc gamma R. - Molecular Immunology 49(1-2): 211-218.

[107] Liu, Q. H., Zhang, S. C., Li, Z. J., Gao, C. R. (2009): Characterization of a pattern recognition molecule vitellogenin from carp (Cyprinus carpio). - Immunobiology 214(4): 257-267.

[108] Liu, S. Y., Sanchez, D. J., Cheng, G. H. (2011b): New developments in the induction and antiviral effectors of type I interferon. - Current Opinion in Immunology 23(1): 57-64. 
[109] Liu, Y., Chen, S. L., Meng, L., Zhang, Y. X. (2007): Cloning, characterization and expression analysis of a novel CXC chemokine from turbot (Scophthalmus maximus). Fish \& Shellfish Immunology 23(4): 711-720.

[110] Low, C., Wadsworth, S., Burrells, C., Secombes, C. J. (2003): Expression of immune genes in turbot (Scophthalmus maximus) fed a nucleotide-supplemented diet. Aquaculture 221(1-4): 23-40.

[111] Lu, A. J., Hu, X. C., Xue, J., Zhu, J. R., Wang, Y., Zhou, G. Z. (2012): Gene expression profiling in the skin of zebrafish infected with Citrobacter freundii. - Fish \& Shellfish Immunology 32(2): 273-283.

[112] Lu, D.-Q., Bei, J.-X., Feng, L.-N., Zhang, Y., Liu, X.-C., Wang, L., Chen, J.-L., Lin, H.R. (2008): Interleukin-1 beta gene in orange-spotted grouper, Epinephelus coioides: Molecular cloning, expression, biological activities and signal transduction. - Molecular Immunology 45(4): 857-867.

[113] Magnadottir, B., Lange, S., Gudmundsdottir, S., Bogwald, J., Dalmo, R. A. (2005): Ontogeny of humoral immune parameters in fish. - Fish \& Shellfish Immunology 19(5): 429-439.

[114] Matsukawa, A., Hogaboam, C. M., Lukacs, N. W., Lincoln, P. M., Evanoff, H. L., Kunkel, S. L. (2000): Pivotal role of the CC chemokine, macrophage-derived chemokine, in the innate immune response. - Journal of Immunology 164(10): 5362-5368.

[115] Medzhitov, R. (2007): Recognition of microorganisms and activation of the immune response. - Nature 449(7164): 819-826.

[116] Medzhitov, R., Janeway, C. A. (2002): Decoding the patterns of self and nonself by the innate immune system. - Science 296(5566): 298-300.

[117] Metz, J. R., Huising, M. O., Leon, K., Verburg-van Kemenade, B. M. L., Flik, G. (2006): Central and peripheral interleukin-1 beta and interieukin-1 receptor I expression and their role in the acute stress response of common carp, Cyprinus carpio L. - Journal of Endocrinology 191(1): 25-35.

[118] Micallef, M. J., Ohtsuki, T., Kohno, K., Tanabe, F., Ushio, S., Namba, M., Tanimoto, T., Torigoe, K., Fuji, M., Ikeda, M., Fukuda, S., Kurimoto, M. (1996): Interferon-gammainducing factor enhances $\mathrm{T}$ helper 1 cytokine production by stimulated human $\mathrm{T}$ cells: Synergism with interleukin-12 for interferon-gamma production. - European Journal of Immunology 26(7): 1647-1651.

[119] Miettinen, M., Sareneva, T., Julkunen, I., Matikainen, S. (2001): IFNs activate toll-like receptor gene expression in viral infections. - Genes and Immunity 2(6): 349-355.

[120] Ming, C., Rui, W., Liping, L., Huang, T., Weiyi, H., Jian, L., Chao, L., Aiying, L., Honglin, L., Wanwen, L. (2013): Sequence and evolution differences of Oreochromis niloticus CXC contribute to the diversification of cellular immune responses in Tilapias with treatment of Streptococcus iniae. - Journal of Animal and Veterinary Advances 12(3): 303-311.

[121] Mladineo, I., Block, B. A. (2010): Expression of cytokines IL-1 beta and TNF-alpha in tissues and cysts surrounding Didymocystis wedli (Digenea, Didymozoidae) in the Pacific bluefin tuna (Thunnus orientalis). - Fish \& Shellfish Immunology 29(3): 487-493.

[122] Mohanty, B. R., Sahoo, P. K. (2010): Immune responses and expression profiles of some immune-related genes in Indian major carp, Labeo rohita to Edwardsiella tarda infection. - Fish \& Shellfish Immunology 28(4): 613-621.

[123] Mulero, J. J., Pace, A. M., Nelken, S. T., Loeb, D. B., Correa, T. R., Drmanac, R., Ford, J. E. (1999): IL1HY1: A novel interleukin-1 receptor antagonist gene. - Biochemical and Biophysical Research Communications 263(3): 702-706.

[124] Murphy, P. M., Baggiolini, M., Charo, I. F., Hebert, C. A., Horuk, R., Matsushima, K., Miller, L. H., Oppenheim, J. J., Power, C. A. (2000): International union of pharmacology. XXII. Nomenclature for chemokine receptors. - Pharmacological Reviews 52(1): 145-176. 
[125] Nagae, M., Fuda, H., Hara, A., Kawamura, H., Yamauchi, K. (1993): Changes in serum immunoglobulin $\mathrm{m}(\mathrm{IgM})$ concentrations during early development of chum Salmon (Oncorhynchus keta) as determined by sensitive ELISA technique. - Comparative Biochemistry and Physiology - Part A 106(1): 69-74.

[126] Najakshin, A. M., Mechetina, L. V., Alabyev, B. Y., Taranin, A. V. (1999): Identification of an IL-8 homolog in lamprey (Lampetra fluviatilis): early evolutionary divergence of chemokines. - European Journal of Immunology 29(2): 375-382.

[127] Nakharuthai, C., Areechon, N., Srisapoome, P. (2016): Molecular characterization, functional analysis, and defense mechanisms of two $C C$ chemokines in Nile tilapia (Oreochromis niloticus) in response to severely pathogenic bacteria. - Developmental and Comparative Immunology 59: 207-228.

[128] Nomiyama, H., Hieshima, K., Osada, N., Kato-Unoki, Y., Otsuka-Ono, K., Takegawa, S., Izawa, T., Yoshizawa, A., Kikuchi, Y., Tanase, S., Miura, R., Kusuda, J., Nakao, M., Yoshie, O. (2008): Extensive expansion and diversification of the chemokine gene family in zebrafish: Identification of a novel chemokine subfamily CX. - BMC Genomics 9(1): 222.

[129] Nordmann, P., Ronco, E., Guenounou, M. (1993): Involvement of interferon-gamma and tumor necrosis factor-alpha in host defense against Rhodococcus equi. - Journal of Infectious Diseases 167(6): 1456-1459.

[130] Palti, Y., Gahr, S. A., Purcell, M. K., Hadidi, S., Rexroad, C. E., Wiens, G. D. (2010): Identification, characterization and genetic mapping of TLR7, TLR8a1 and TLR8a2 genes in rainbow trout (Oncorhynchus mykiss). - Developmental and Comparative Immunology 34(2): 219-233.

[131] Pan, G. H., Risser, P., Mao, W. G., Baldwin, D. T., Zhong, A. W., Filvaroff, E., Yansura, D., Lewis, L., Eigenbrot, C., Henzel, W. J., Vandlen, R. (2001): IL-1H, an interleukin 1related protein that binds IL-18 receptor/IL-1Rrp. - Cytokine 13(1): 1-7.

[132] Peatman, E., Liu, Z. J. (2007): Evolution of CC chemokines in teleost fish: a case study in gene duplication and implications for immune diversity. - Immunogenetics 59(8): 613623.

[133] Pichlmair, A., Sousa, C. R. E. (2007): Innate recognition of viruses. - Immunity 27(3): 370-383.

[134] Poisa-Beiro, L., Dios, S., Montes, A., Aranguren, R., Figueras, A., Novoa, B. (2008): Nodavirus increases the expression of $\mathrm{Mx}$ and inflammatory cytokines in fish brain. Molecular Immunology 45(1): 218-225.

[135] Praveen, K., Evans, D. L., Jaso-Friedmann, L. (2006a): Constitutive expression of tumor necrosis factor-alpha in cytotoxic cells of teleosts and its role in regulation of cellmediated cytotoxicity. - Molecular Immunology 43(3): 279-291.

[136] Praveen, K., Leary, J. H., Evans, D. L., Jaso-Friedmann, L. (2006b): Molecular cloning of cellular apoptosis susceptibility (CAS) gene in Oreochromis niloticus and its proposed role in regulation of non-specific cytotoxic cell (NCC) functions. - Fish \& Shellfish Immunology 20(4): 647-655.

[137] Puerto, M., Gutierrez-Praena, D., Prieto, A., Pichardo, S., Jos, A., Miguel-Carrasco, J., Vazquez, C., Camean, A. M. (2011): Subchronic effects of cyanobacterial cells on the transcription of antioxidant enzyme genes in tilapia (Oreochromis niloticus). Ecotoxicology 20(2): 479-490.

[138] Purcell, M. K., Kurath, G., Garver, K. A., Herwig, R. P., Winton, J. R. (2004): Quantitative expression profiling of immune response genes in rainbow trout following infectious haematopoietic necrosis virus (IHNV) infection or DNA vaccination. - Fish \& Shellfish Immunology 17(5): 447-462.

[139] Qin, Q. W., Ototake, M., Noguchi, K., Soma, G. I., Yokomizo, Y., Nakanishi, T. (2001): Tumor necrosis factor alpha (TNF alpha)-like factor produced by macrophages in rainbow trout, Oncorhynchus mykiss. - Fish \& Shellfish Immunology 11(3): 245-256. 
[140] Randelli, E., Buonocore, F., Scapigliati, G. (2008): Cell markers and determinants in fish immunology. - Fish \& Shellfish Immunology 25(4): 326-340.

[141] Rauta, P. R., Samanta, M., Dash, H. R., Nayak, B., Das, S. (2014): Toll-like receptors (TLRs) in aquatic animals: Signaling pathways, expressions and immune responses. Immunology Letters 158(1-2): 14-24.

[142] Reda, R. M., Mahmoud, R., Selim, K. M., El-Araby, I. E. (2016): Effects of dietary acidifiers on growth, hematology, immune response and disease resistance of Nile tilapia, Oreochromis niloticus. - Fish \& Shellfish Immunology 50: 255-262.

[143] Sadler, A. J., Williams, B. R. G. (2008): Interferon-inducible antiviral effectors. - Nature Reviews Immunology 8(7): 559-568.

[144] Salaun, B., Romero, P., Lebecque, S. (2007): Toll-like receptors' two-edged sword: when immunity meets apoptosis. - European Journal of Immunology 37(12): 3311-3318.

[145] Samuel, C. E. (1991): Antiviral actions of interferon - interferon-regulated cellular proteins and their surprisingly selective antiviral activities. - Virology 183(1): 1-11.

[146] Saurabh, S., Mohanty, B. R., Sahoo, P. K. (2011): Expression of immune-related genes in rohu Labeo rohita (Hamilton) by experimental freshwater lice Argulus siamensis (Wilson) infection. - Veterinary Parasitology 175(1-2): 119-128.

[147] Savan, R., Sakai, M. (2004): Presence of multiple isoforms of TNF alpha in carp (Cyprinus carpio L.): genomic and expression analysis. - Fish \& Shellfish Immunology 17(1): 87-94.

[148] Savan, R., Igawa, D., Sakai, M. (2003): Cloning, characterization and expression analysis of interleukin-10 from the common carp, Cyprinus carpio L. - European Journal of Biochemistry 270(23): 4647-4654.

[149] Scherf, U., Pastan, I., Willingham, M. C., Brinkmann, U. (1996): The human CAS protein which is homologous to the CSE1 yeast chromosome segregation gene product is associated with microtubules and mitotic spindle. - Proceedings of the National Academy of Sciences of the United States of America 93(7): 2670-2674.

[150] Schroder, K., Hertzog, P. J., Ravasi, T., Hume, D. A. (2004): Interferon-gamma: an overview of signals, mechanisms and functions. - Journal of Leukocyte Biology 75(2): 163-189.

[151] Schultz, U., Kaspers, B., Staeheli, P. (2004): The interferon system of non-mammalian vertebrates. - Developmental and Comparative Immunology 28(5): 499-508.

[152] Scott, K., Leaver, M. J., George, S. G. (1992): Regulation of hepatic glutathione-Stransferase expression in flounder. - Marine Environmental Research 34(1-4): 233-236.

[153] Secombes, C. J., Wang, T., Hong, S., Peddie, S., Crampe, M., Laing, K. J., Cunningham, C., Zou, J. (2001): Cytokines and innate immunity of fish. - Developmental and Comparative Immunology 25(8-9): 713-723.

[154] Smith, D. E., Renshaw, B. R., Ketchem, R. R., Kubin, M., Garka, K. E., Sims, J. E. (2000): Four new members expand the interleukin-1 superfamily. - Journal of Biological Chemistry 275(2): 1169-1175.

[155] Staeheli, P., Yu, Y. X., Grob, R., Haller, O. (1989): A double-stranded RNA-inducible fish gene homologous to the murine influenza-virus resistance gene $M x$. - Molecular and Cellular Biology 9(7): 3117-3121.

[156] Stolte, E. H., Savelkoul, H. F. J., Wiegertjes, G., Flik, G., Verburg-van Kemenade, B. M. L. (2008): Differential expression of two interferon-gamma genes in common carp (Cyprinus carpio L.). - Developmental and Comparative Immunology 32(12): 14671481.

[157] Stranden, A. M., Staeheli, P., Pavlovic, J. (1993): Function of the mouse Mx1 protein is inhibited by overexpression of the PB2 protein of influenza-virus. - Virology 197(2): 642-651.

[158] Su, Y. L., Guo, Z. X., Xu, L. W., Jiang, J. Z., Wang, J. Y., Feng, J. (2012): Identification of a cobia (Rachycentron canadum) CC chemokine gene and its involvement in the inflammatory response. - Fish \& Shellfish Immunology 32(1): 204-210. 
[159] Sun, B. J., Robertsen, B., Wang, Z. Q., Bin, L. (2009): Identification of an Atlantic salmon IFN multigene cluster encoding three IFN subtypes with very different expression properties. - Developmental and Comparative Immunology 33(4): 547-558.

[160] Sun, J. S., Zhao, L., Sun, L. (2011): Interleukin-8 of Cynoglossus semilaevis is a chemoattractant with immunoregulatory property. - Fish \& Shellfish Immunology 30(6): 1362-1367.

[161] Svingerud, T., Solstad, T., Sun, B. J., Nyrud, M. L. J., Kileng, O., Greiner-Tollersrud, L., Robertsen, B. (2012): Atlantic salmon type I IFN subtypes show differences in antiviral activity and cell-dependent expression: Evidence for high IFNb/IFNc-producing cells in fish lymphoid tissues. - Journal of Immunology 189(12): 5912-5923.

[162] Tafalla, C., Aranguren, R., Secombes, C. J., Figueras, A., Novoa, B. (2004): Cloning and analysis of expression of a gilthead sea bream (Sparus aurata) Mx cDNA. - Fish \& Shellfish Immunology 16(1): 11-24.

[163] Tafalla, C., Coll, J., Secombes, C. J. (2005): Expression of genes related to the early immune response in rainbow trout (Oncorhynchus mykiss) after viral haemorrhagic septicemia virus (VHSV) infection. - Developmental and Comparative Immunology 29(7): 615-626.

[164] Takeda, K., Akira, S. (2001): Roles of Toll-like receptors in innate immune responses. Genes to Cells 6(9): 733-742.

[165] Takemura, A. (1993): Changes in an immunoglobulin M (IgM)-like protein during larval stages in Tilapia, Oreochromis mossambicus. - Aquaculture 115(3-4): 233-241.

[166] Tanekhy, M., Kono, T., Sakai, M. (2010): Cloning, characterization, and expression analysis of Toll-like receptor-7 cDNA from common carp, Cyprinus carpio L. Comparative Biochemistry and Physiology - Part D 5(4): 245-255.

[167] Tassakka, A. C. M. A. R., Sakai, M. (2004): Expression of immune-related genes in the common carp (Cyprinus carpio L.) after stimulation by $\mathrm{CpG}$ oligodeoxynucleotides. Aquaculture 242(1-4): 1-12.

[168] Tellez-Banuelos, M. C., Santerre, A., Casas-Solis, J., Zaitseva, G. (2010): Endosulfan increases seric interleukin-2 like (IL-2L) factor and immunoglobulin M (IgM) of Nile tilapia (Oreochromis niloticus) challenged with Aeromona hydrophila. - Fish \& Shellfish Immunology 28(2): 401-405.

[169] Tortorella, D., Gewurz, B. E., Furman, M. H., Schust, D. J., Ploegh, H. L. (2000): Viral subversion of the immune system. - Annual Review of Immunology 18: 861-926.

[170] Van der Aa, L. M., Chadzinska, M., Golbach, L. A., Ribeiro, C. M. S., Verburg-van Kemenade, B. M. L. (2012): Pro-inflammatory functions of carp CXCL8-like and CXCb chemokines. - Developmental and Comparative Immunology 36(4): 741-750.

[171] Vandercappellen, J., Van Damme, J., Struyf, S. (2008): The role of CXC chemokines and their receptors in cancer. - Cancer Letters 267(2): 226-244.

[172] Verrier, E. R., Langevin, C., Benmansour, A., Boudinot, P. (2011): Early antiviral response and virus-induced genes in fish. - Developmental and Comparative Immunology 35(12): 1204-1214.

[173] Villalta, F., Zhang, Y., Bibb, K. E., Kappes, J. C., Lima, M. F. (1998): The cysteinecysteine family of chemokines RANTES, MIP-1 alpha, and MIP-1 beta induce trypanocidal activity in human macrophages via nitric oxide. - Infection and Immunity 66(10): 4690-4695.

[174] Wan, Y. Y., Flavell, R. A. (2009): How diverse-CD4 effector T cells and their functions. - Journal of Molecular Cell Biology 1(1): 20-36.

[175] Wang, C. Y., Zhao, J. M., Mu, C. K., Wang, Q., Wu, H. F., Wang, C. L. (2013): cDNA cloning and mRNA expression of four glutathione $S$-transferase (GST) genes from Mytilus galloprovincialis. - Fish \& Shellfish Immunology 34(2): 697-703.

[176] Wang, J. X., Shi, X. J., Du, Y. B., Zhou, B. S. (2011): Effects of xenoestrogens on the expression of vitellogenin ( $v t g$ ) and cytochrome P450 aromatase (cyp19a and $b$ ) genes in 
zebrafish (Danio rerio) larvae. - Journal of Environmental Science and Health - Part A 46(9): 960-967.

[177] Wang, T. H., Holland, J. W., Bols, N., Secombes, C. J. (2005): Cloning and expression of the first nonmammalian interleukin-11 gene in rainbow trout Oncorhynchus mykiss. FEBS Journal 272(5): 1136-1147.

[178] Warr, G. W. (1995): The immunoglobulin genes of fish. - Developmental and Comparative Immunology 19(1): 1-12.

[179] Warren, D. W., Pasupuleti, V., Lu, Y., Platler, B. W., Horton, R. (1990): Tumor necrosis factor and interleukin-1 stimulate testosterone secretion in adult male rat Leydig cells in vitro. - Journal of Andrology 11(4): 353-360.

[180] Warringa, R. A. J., Koenderman, L., Kok, P. T. M., Kreukniet, J., Bruijnzeel, P. L. B. (1991): Modulation and induction of eosinophil chemotaxis by granulocyte-macrophage colony-stimulating factor and interleukin-3. - Blood 77(12): 2694-2700.

[181] White, M. V., Yoshimura, T., Hook, W., Kaliner, M. A., Leonard, E. J. (1989): Neutrophil attractant activation protein-1 (Nap-1) causes human basophil histaminerelease. - Immunology Letters 22(2): 151-154.

[182] Wrzesien-Kus, A., Smolewski, P., Sobczak-Pluta, A., Wierzbowska, A., Robak, T. (2004): The inhibitor of apoptosis protein family and its antagonists in acute leukemias. Apoptosis 9(6): 705-715.

[183] Yan, Z., Hunter, V., Weed, J., Hutchison, S., Lyles, R., Terranova, P. (1993): Tumor necrosis factor-alpha alters steroidogenesis and stimulates proliferation of human ovarian granulosal cells in vitro. - Fertility and Sterility 59(2): 332-338.

[184] Yoshiura, Y., Kiryu, I., Fujiwara, A., Suetake, H., Suzuki, Y., Nakanishi, T., Ototake, M. (2003): Identification and characterization of Fugu orthologues of mammalian interleukin-12 subunits. - Immunogenetics 55(5): 296-306.

[185] Zhang, J., Chen, L. P., Wei, X. L., Xu, M. X., Huang, C. X., Wang, W. M., Wang, H. L. (2014a): Characterization of a novel CC chemokine CCL4 in immune response induced by nitrite and its expression differences among three populations of Megalobrama amblycephala. - Fish \& Shellfish Immunology 38(1): 88-95.

[186] Zhang, J. Z., Ao, J. Q., Chen, X. H. (2008): Molecular and functional characterization of a novel CC chemokine in large yellow croaker (Pseudosciaena crocea). - Fish \& Shellfish Immunology 25(5): 664-671.

[187] Zhang, S. C., Sun, Y. N., Pang, Q. X., Shi, X. D. (2005): Hemagglutinating and antibacterial activities of vitellogenin. - Fish \& Shellfish Immunology 19(1): 93-95.

[188] Zhang, S. C., Wang, S. H., Li, H. Y., Li, L. (2011): Vitellogenin, a multivalent sensor and an antimicrobial effector. - International Journal of Biochemistry \& Cell Biology 43(3): 303-305.

[189] Zhang, Y. B., Gui, J. F. (2012): Molecular regulation of interferon antiviral response in fish. - Developmental and Comparative Immunology 38(2): 193-202.

[190] Zhang, Z., Xu, L., Liu, W. S., Yang, Y. L., Du, Z. Y., Zhou, Z. G. (2014b): Effects of partially replacing dietary soybean meal or cottonseed meal with completely hydrolyzed feather meal (defatted rice bran as the carrier) on production, cytokines, adhesive gut bacteria, and disease resistance in hybrid tilapia (Oreochromis niloticus female $\mathrm{x}$ Oreochromis aureus male). - Fish \& Shellfish Immunology 41(2): 517-525.

[191] Zhao, F., Li, Y. W., Pan, H. J., Shi, C. B., Luo, X. C., Li, A. X., Wu, S. Q. (2013): Expression profiles of toll-like receptors in channel catfish (Ictalurus punctatus) after infection with Ichthyophthirius multifiliis. - Fish \& Shellfish Immunology 35(3): 993 997.

[192] Zhao, Y., Nichols, J. E., Valdez, R., Mendelson, C. R., Simpson, E. R. (1996): Tumor necrosis factor-alpha stimulates aromatase gene expression in human adipose stromal cells through use of an activating protein-1 binding site upstream of promoter 1.4. Molecular Endocrinology 10(11): 1350-1357. 
[193] Zou, J., Secombes, C. J. (2011): Teleost fish interferons and their role in immunity. Developmental and Comparative Immunology 35(12): 1376-1387.

[194] Zou, J., Cunningham, C., Secombes, C. J. (1999): The rainbow trout Oncorhynchus mykiss interleukin-1 beta gene has a different organization to mammals and undergoes incomplete splicing. - European Journal of Biochemistry 259(3): 901-908.

[195] Zou, J., Peddie, S., Scapigliati, G., Zhang, Y., Bols, N. C., Ellis, A. E., Secombes, C. J. (2003): Functional characterisation of the recombinant tumor necrosis factors in rainbow trout, Oncorhynchus mykiss. - Developmental and Comparative Immunology 27(9): 813822.

[196] Zou, J., Bird, S., Truckle, J., Bols, N., Horne, M., Secombes, C. (2004a): Identification and expression analysis of an IL-18 homologue and its alternatively spliced form in rainbow trout (Oncorhynchus mykiss). - European Journal of Biochemistry 271(10): 1913-1923.

[197] Zou, J., Yasutoshi, Y. B., Dijkstra, J. M., Sakai, M., Ototake, M., Secombes, C. (2004b): Identification of an interferon gamma homologue in Fugu, Takifugu rubripes. - Fish \& Shellfish Immunology 17(4): 403-409. 